Journal of Agriculture and Social Research (JASR) Vol. 8, No. 2, 2008

\title{
SMALL-SCALE FAMILY POULTRY PRODUCTION AS A SUBSTANTIAL SOURCE OF ANIMAL PROTEIN IN SELECTED LOCAL GOVERNMENT AREAS IN RIVERS STATE
}

\author{
L. A. F AKINOLA ${ }^{1}$ AND O. S. GEORGE ${ }^{2}$ \\ ${ }^{1}$ Department of Animal Science and Fisheries, Faculty of Agriculture, University of Port \\ Harcourt, P. M. B. 5323 Port Harcourt, Rivers State. \\ ${ }^{2}$ Nutrition and Feedmill Unit, African Regional Aquacultural Centre/Nigerian Institute \\ for Oceanography and Marine Research, Buguma Station, P. M. B. 5122 Port Harcourt, \\ Rivers State. \\ ${ }^{1}$ Corresponding Author
}

\begin{abstract}
A survey was conducted through structured questionnaires to find out consumers' preference for local chicken, its production and consumption in khana, Gokana, Tai and Eleme Local Government Areas (LGAs) making up the Ogoni kingdom in Rivers State, Nigeria. The data collected were analyzed using frequency counts, percentages and ranking. The result showed that the 3 most available and preferred species of poultry were local chicken (47.5\%), layer birds (21.9\%) and broilers (17.5\%). Most of the respondents agreed that although productivity of local fowl had fallen compared to the last 5 years, chicken meat was still popular, more available for sales and a relatively cheap source of meat and eggs for rural dwellers. The major reason given for reduced productivity was rural-urban drift in search of education and paid jobs. It is therefore believed that a sensitization campaign aimed at encouraging small and medium scale local chicken production organized by government agencies and/or nongovernmental organizations will be a sure way of increasing animal protein supply, generate employment opportunities for youths and women, increase income, alleviate poverty, reduce rural-urban drift and enhance rural livelihood in Ogoni area.
\end{abstract}

Key words: Local chicken, family poultry, and protein source, rural communities.

\section{INTRODUCTION}

About $70 \%$ of Nigerians live below the poverty line earning less than the current $\$ 2$ per capital income. The effect of poverty is therefore felt more among rural dwellers, those with limited education and the unemployed. Parallel to commercial poultry industry, a small-scale poultry production system had been developed and remains part of most rural communities in developing countries. The term 'rural poultry' or 'family poultry' (FP), as used in most developing countries, is indicative of the traditional low input husbandry of domestic poultry such as chicken, duck, pigeon, quail and guinea fowl that is typically maintained by the rural poor (somewhat similar to backyard chicken on a wider concept). Sonaiya (2007) defined rural poultry as involving any genetic stock; improved or unimproved that is raised extensively or semi-intensively in relatively small numbers (usually less than 100 birds at a time). Poultry is owned by many families including even the very poor ones and has the potential of eliminating poverty, as poverty reduction according to Yunus (1998), is a continuous process of asset creation, investment and savings. With this kind of production, the so- called backyard poultry, these systems can be an important source of food in rural areas, Sheldon (1993) and a sure way of reducing poverty. Backyard poultry enables the rural poor, including the landless to create an asset base with minimum input. Sheldon (2000) stated that research on the small-scale poultry production system has to be a priority in the scientific poultry community in years to come. Although these birds were reported to make up more than $80 \%$ of African's poultry flock, Gueye (2000), with Africa's household flock size ranging from 3 to 97, Sonaiya et al (1999) and 


\section{Journal of Agriculture and Social Research (JASR) Vol. 8, No. 2, 2008}

1 to 95 , Gueye (2003), this reality had declined in most communities in the Niger Delta and especially in Rivers State during the past decade. It is clear that animal protein intake of rural dwellers in the Niger Delta region of Nigeria is less than the $17 \%$ per diet reported by World Bank (2001) compared to more than $60 \%$ obtainable in developed countries. This is due to massive drift of man-power from the rural areas to the urban cities in search of education and white-collar jobs.

A strategic plan to reposition local chicken production and consumption will greatly increase the animal protein intake of rural dwellers. This study was therefore carried out in Khana, Gokana, Tai and Eleme LGAs (Ogoni Kingdom) in Rivers State in 2008 to ascertain the present preference for local chicken (meat and eggs) for the rural populace.

\section{MATERIALS AND METHODS}

The study was set up as simple descriptive survey to obtain relevant information from respondents on the preference for local chicken meat as a protein source in 4 LGAs making up the Ogoni kingdom in Rivers State. Four (4) autonomous communities were selected in each LGA for the study. These were Kaani 1, Lueku, Gwara and Kono in Khana LGA; Biara, Nweol, Bodo and B-Dere in Gokana LGA; Sime, Koro-koro, Norwa and Bonu in Tai LGA and Eteo, Akpajo, Nc hia and Onne in Eleme LGA. Twenty (20) local chicken owners managing their individual family poultry, with sizes ranging from at least 1-30 birds were randomly selected from each community making up a total of three hundred and twenty (320) respondents from the 4 LGAs. Data collection was done through structured questionnaires administered to the respondents who were grouped within 4 age brackets. The study lasted from February to April 2008. Completed questionnaires were retrieved and analysed through descriptive statistics using the averages from the 4 LGAs and simple percentages.

\section{RESULTS AND DISCUSSION}

Result from the study showed that the people of Ogoni in Rivers State obtained poultry meat and eggs from different poultry species, Table 1 . Among the poultry species identified, local chicken was the most available $(47.5 \%)$ while quail was the least available $(1.6 \%)$. This may be expected due to the high number of chickens estimated in Africa in 2005 (1,356 million) compared to 16 million ducks 12 million geese and guinea fowl and 9 million turkeys (FAO statistics). In terms of the respondents' preference for meat, the least preferred was quail $(2.2 \%)$ while the most preferred was local chicken meat $(40 \%)$. This may be as a result of non-availability and awareness of quail meat in most communities in Ogoni. Presently, quail is produced on commercial bases only at the National Veterinary Research Institute (NVRI) Vom, Plateau State. Majority of the respondent (88.1\%) also agreed that local chickens were the most available meat for sales among the poultry species in the kingdom. Many of them (62.8\%) also confirmed that chicken meat was relatively cheap. This may be due to the free range and semi-intensive systems of management used in these rural communities which reduces the cost of production. Majority of the respondents $(56.3 \%)$ agreed that local chicken production had decreased compared to the last 5 years. This according to them may be due to the increasing number of undergraduates who had left home for school and graduates from each family who seek for paid (white- collar) jobs in urban areas, coupled with the normal rural-urban drift in search of better jobs, amenities and good environment. The low number of respondents in the 2 categories, below the age of 38 years also confirm this finding. The data obtained showed that most of the local chicken farmers maintained a house-hold flock size of 1 to 40 birds in Ogoni Kingdom. This reduced range according to them was for easy management by the elderly family members who cannot cope with a larger flock. The range in age of respondents indicated that $68.1 \%$ of them were above 47 years while the least response $(9.7 \%)$ was obtain from those in age bracket of $38-47$ years. Some of the factors identified for the continuous existence and preference for local chicken were the 


\section{Journal of Agriculture and Social Research (JASR) Vol. 8, No. 2, 2008}

high disease resistance of the birds, their scavenging ability which make them to survive with little or no proprietary concentrate feed, low production cost, their high prolific nature and their hardy but juicy meat which is highly preferred by rural dwellers.

\section{CONCLUSION}

This study had shown that local chicken is a substantial source of animal protein for the rural populace of Khana, Gokana Tai and Eleme L.G.As (Ogoni Kindom) in Rivers State. The study noted that the major obstacle to family poultry production in the area was rural-urban drift in search of education and white-collar jobs. It is therefore believed that a sensitization campaign aimed at encouraging small and medium scale family poultry production organized by government agencies and/or non- governmental organizations is a sure way of increasing animal protein supply, creating jobs, increasing income, reducing rural-urban drift and eradicating poverty in the area.

\section{REFERENCES}

Gueye, E.F. (2000). The role of family poultry in poverty alleviation, food security and the promotion of gender equality in rural Africa. Outlook on Agriculture 29: 129-136

Gueye, E.F. (2003). Proverty alleviation, food security and well being of the human population through famly poultry in low- income food deficit countries. J. of Agric and Envt. 1(2) $: 12-21$

Sheldon, B.L. (1993). Opportunities and challenges for application of poultry science and technology into the $21^{\text {st }}$ century. Proc. $5^{\text {th }}$ conf. for East and South pacific Fed., WPSA, Seoul Korea. Pp. 17-25

Sheldon, B.L. (2000). Research and development in 2000: Directions and priorities for the World's poultry science community. Poultry science 79:147-158

Sonaiya, E.B. (2007). Family Poultry, Food security and the impact of HPAI. World Poultry, science Journal 63:132-138

Sonaiya, E.B., Brankaert, R.D.S and Gueye, E.F. (1999). Research and development options for family poultry. Introductory paper to the first INFPD/FAO Electrionic Conference on the Scope and Effect of Family poultry Research and Development. www.Fao.org/wa.cent/ faoinfo/agricult/aga/agap/ipa/ fampol/intropap. htm

Yunus, M. (1998). Banker to the poor. Dhaka, Bangladesh: the University Press Ltd. (autobiographical account of founder of Graamen Bank).

World Bank (2001). World Development Report 2000/2001.

Attacking poverty. Oxford

University Press, New York, USA, 335pp 
Journal of Agriculture and Social Research (JASR) Vol. 8, No. 2, 2008

Table 1 : Responses on poultry meat availability and preference in Ogoni Kingdom (Khana, Gokana, Tai and Eleme LGAs) in Rivers State.

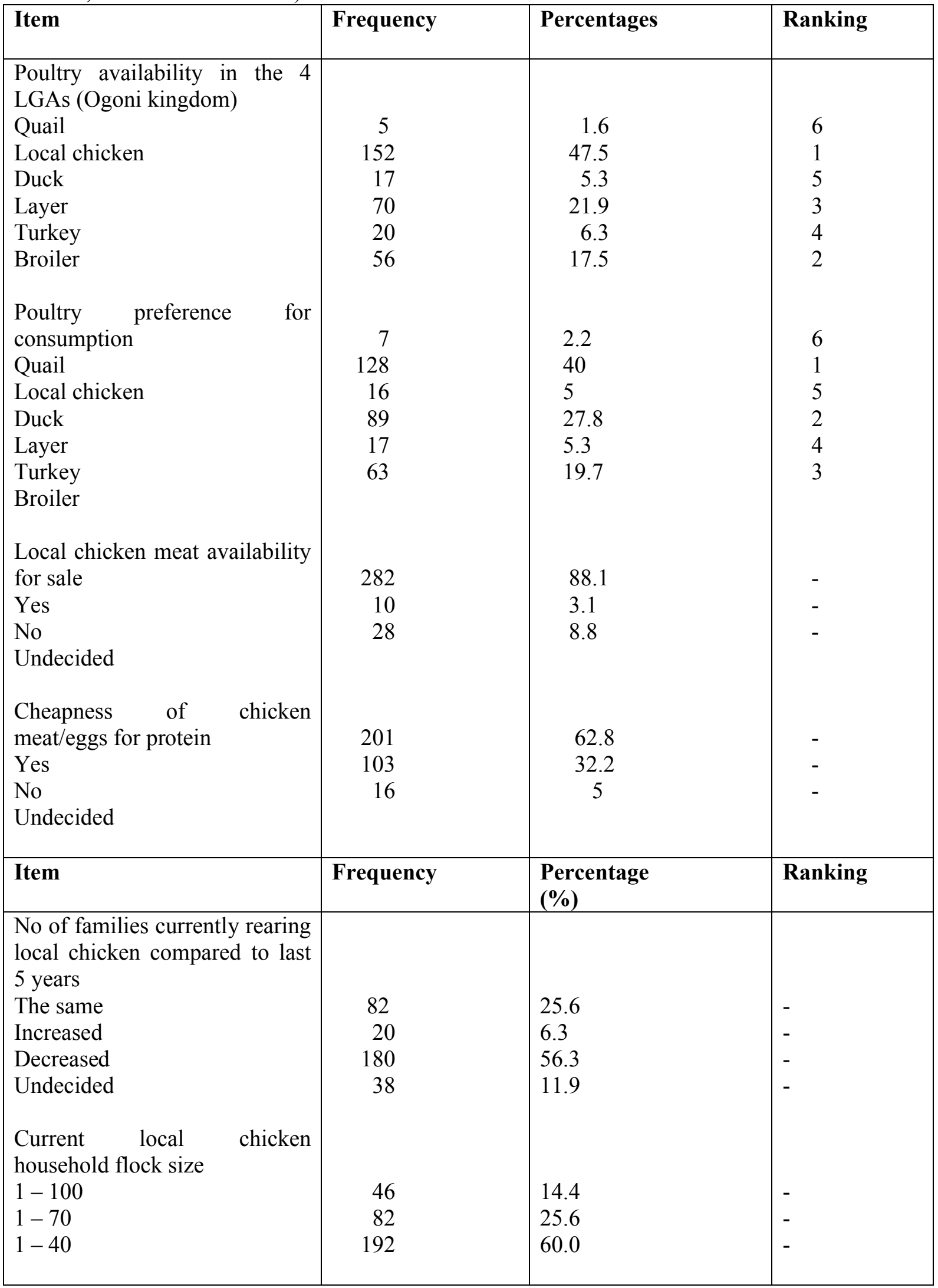


Journal of Agriculture and Social Research (JASR) Vol. 8, No. 2, 2008

\begin{tabular}{|l|r|l|l|}
\hline Age of respondents (years) & 36 & 11.3 & - \\
$18-27$ & 35 & 10.9 & - \\
$28-37$ & 31 & 9.7 & - \\
$38-47$ & 218 & 68.1 & - \\
$>47$ & & & \\
\hline
\end{tabular}

